\title{
Fauna, Seasonal Activity, and Altitudinal Distribution of Phlebotomine Sand Flies (Diptera: Psychodidae) in Leishmaniasis Endemic Area, Aydın Mountains, and Surroundings in Western Turkey
}

\author{
Türkiye’nin Batısında, Leishmaniasis'in Endemik Olduğu Aydın Dağları \\ ve Çevresinde Kum Sineği (Diptera: Psychodidae) Faunast, Mevsimsel \\ Aktiviteleri ve Yüksekliğe Göre Dağılimlan
}

\author{
(1) Süha Kenan Arserim¹ (1) Ahmet Mermer², (1) Yusuf Özbel ${ }^{3}$ \\ ${ }^{1}$ Manisa Celal Bayar University, Vocational School of Health Services, Manisa, Turkey \\ ${ }^{2}$ Ege University Faculty of Science, Department of Biology, İzmir, Turkey \\ ${ }^{3}$ Ege University Faculty of Medicine, Department of Parasitology, İzmir, Turkey
}

Cite this article as: Arserim SK, Mermer A, Özbel Y. Fauna, Seasonal Activity, and Altitudinal Distribution of

Phlebotomine Sand Flies (Diptera: Psychodidae) in Leishmaniasis Endemic Area, Aydın Mountains, and Surroundings in Western Turkey. Turkiye Parazitol Derg 2022;46(1):60-71.

\begin{abstract}
Objective: Human and canine leishmaniasis (CanL) are endemic in Turkey, and cutaneous leishmaniasis (CL) is a primary public health problem among vector-borne diseases, with 1500-2000 autochthonous cases per year. In this study, we aimed to perform a comprehensive entomological survey, including the detection of sand fly fauna, seasonal activity, and altitudinal distribution, together with the ecological features of Aydın Mountains and their surroundings that are endemic areas for CL caused by Leishmania tropica and CanL caused by L. infantum MON-1.

Methods: The survey was carried out from June 2009 to July 2010. Ten localities with different altitudes were selected. Sand fly collection was done every 15 days in July and August when sand flies are most active and every 30 days between September and June (14 months, 16 samplings) using CDC light traps and sticky traps. During the collection, the temperature, humidity, and ecological and environmental features were recorded. Sand fly specimens were dissected and identified at species level using written keys.

Results: A total of 6712 sand fly specimens (3268 females and 3444 males) were collected from 10 localities throughout all study periods. Species identification revealed that nine and three species belonging to Phlebotomus (P. major s.1. 30.38\%, P. tobbi 22.93\%, P. papatasi $5.88 \%$, P. sergenti s.1. $4.51 \%$, P. alexandri $4.26 \%$, P. simici $3.50 \%$, P. burneyi $0.63 \%$, P. brevis $0.45 \%$, and Transphlebotomus spp. $0.28 \%$ ) and Sergentomyia (S. dentata $23.17 \%$, S. minuta $2.43 \%$, and S. antennata $1.58 \%$ ) were found, respectively. The seasonal activities of these 12 sand fly species were determined, and P. major s.l. and P. tobbi, which were probable vectors of VL and CanL, were present in the study area. P. sergenti s.l., a probable vector of CL, was also found in the region and was active for seven months between April and October. P. sergenti s.l. was found in the 400-600 m altitude in July, while P. major and P. tobbi were found in high densities in the 200-400 m altitude in September.

Conclusion: Our results showed that leishmaniasis vectors are present in different altitudes in the Aydın mountains and surroundings. The findings revealed the time intervals of parasite transmission in the area and the period of applying protective measures, such as insecticide application.
\end{abstract}

Keywords: Sandy fly, seasonal activity, leishmaniasis, Aydın Mountains, Western Anatolia

Received/Geliş Tarihi: 15.12.2021 Accepted/Kabul Tarihi: 21.02.2022

Address for Correspondence/Yazar Adresi: Süha Kenan Arserim, Manisa Celal Bayar University, Vocational School of Health Services, Manisa, Turkey Phone/Tel: +90 5053569336 E-mail/E-Posta: suhaarserim@hotmail.com ORCID ID: orcid.org/0000-0002-9174-6291 
ÖZ

Amaç: İnsan ve kanin leishmaniasis (CanL) açısından endemik bir ülke olan Türkiye'de, kutanöz leishmaniasis (KL) yllda 1500-2000 yerli olgu ile vektör kaynaklı hastalıklar arasında birincil halk sağlığı sorunudur. Bu çalışmada, Leishmania tropica'nın neden olduğu CL ve L. infantum MON-1'in neden olduğu CanL bakımından endemik bir alan olan Aydın Dağları ve çevresinde bulunan kum sineğinin faunası, mevsimsel aktiviteleri ve yüksekliğe göre dağılımları ile ekolojik özelliklerinin de belirlenmesini içeren kapsamlı bir entomolojik araştırma amaçlanmıştır.

Yöntemler: Araştırma, Haziran 2009 ile Temmuz 2010 tarihleri arasında gerçekleştirilmiştir. Farklı yükseklik aralıklarına göre toplam 10 lokasyon seçilmiş, CDC 1şık tuzakları ve yapışkan tuzaklar kullanılarak kum sineklerinin en aktif olduğu Temmuz ve Ağustos aylarında 15 günde bir, Eylül ve Haziran ayları arasında 30 günde bir olmak üzere kum sineği örnekleri toplanmıştır (toplam 14 ay, 16 örnekleme). Örnek toplama sırasında sıcaklık, nem, ekolojik ve çevresel özellikler kaydedilmiştir. Kum sineği örnekleri, teşhis anahtarları kullanılarak tür düzeyinde tanımlanmıştır.

Bulgular: Tüm örnekleme periyotları boyunca, 10 lokasyondan toplam 6712 kum sineği örneği (3268 diși ve 3444 erkek) toplanmıştır. Morfolojik tür teşhisinde Phlebotomus cinsine ait dokuz (P. major s.1. \%30,38; P. tobbi \%22,93; P. papatasi \%5,88; P. sergenti s.l. \%4,51; P. alexandri \%4,26; P. simici \%3,50; P. burneyi \%0,63; P. brevis \%0,45; Transphlebotomus spp. \%0,28) ve Sergentomyia cinsine ait üç tür (S. dentata \%23,17; S. minuta \%2,43; S. antennata \%1,58) bulunmuştur. On iki kum sineği türünün mevsimsel aktivitesi belirlenmiş, VL ve CanL'nin olası vektörleri olan $P$. major s.l. ve $P$. tobbi ile CL'nin olası vektörü olan $P$. sergenti s.l de çalışma alanında bulunmuş olup, Nisan ile Ekim ayları arasında yedi ay boyunca aktivite gösterdikleri saptanmıştır. P. sergenti s.l'nin Temmuz ayında 400-600 m'de, P. major ve P. tobbi'nin ise Eylül ayında 200-400 m yükseklik aralığında en fazla yoğunluğa sahip olduğu tespit edilmiştir. Sonuç: Sonuçlar, Aydın Dağları ve çevresinde leishmaniasis vektörlerinin farklı yüksekliklerde bulunduğunu göstermiştir. Elde edilen bulgular, çalışma alanında parazitin bulaşma dönemi ve insektisit uygulaması gibi koruyucu önlemlerin uygulama periyodunu ortaya koymuştur.

Anahtar Kelimeler: Kum sineği, mevsimsel aktivite, leishmaniasis, Aydın Dağları, Batı Anadolu

\section{INTRODUCTION}

Phlebotominae sand flies play a role in the transmission of different Leishmania species that cause leishmaniasis, as well as bacteria (Bartonella bacilliformis) and various phleboviruses. In addition, sand fly bites can cause allergic reactions in sensitive people (1-6). More than one thousand species of sand flies have been identified in the New and Old World, but only $10 \%$ of them are proven or probable vectors of the Leishmania species in mammalians including humans (7-9). The species belonging to Phlebotomus genus (Diptera: Phlebotomidae) are very important because they are the biological vectors of different Leishmania species and phleboviruses in the Old-World countries including Turkey (10).

All clinical forms of leishmaniasis are still one of the most neglected diseases of the world and generally affect developing countries. Two million cases occur every year and 350 million people in the world are at risk of infection according to World Health Organization reports. Over the past decade, scientific approaches have been developed in the diagnosis, treatment and prevention measures against leishmaniasis to facilitate sustainable implementation of national and regional control programs (11). To date, no vaccines or drugs have been developed to provide long-term protection and effective immunity human against leishmaniasis (12). Therefore, vector control in integrated control programs has gained great importance for fighting these diseases $(13,14)$.

Turkey is a bridge between Europe and Asia/Middle East and has different ecological and climatic features. Zoonotic cutaneous leishmaniasis (ZCL), anthroponotic cutaneous leishmaniasis (ACL) and zoonotic visceral leishmaniasis (ZVL) in humans, and canine leishmaniasis ( $\mathrm{CanL}$ ) in dogs are commonly seen in Turkey (15).

Understanding the population dynamics and ecological characteristics of Phlebotomus species, their vectorial capacity in the particular areas where the disease is endemic, and the epidemiological features are important for the development of integrated vector control strategies (16). Therefore, entomological studies performed in different regions of Turkey are mainly in the areas where visceral and/or cutaneous leishmaniasis is endemic.
Although ACL is often seen in southeastern Turkey and the eastern part of the Mediterranean, it is mainly reported from Aydin province in the western part of Turkey. Additionally, CanL cases have also been reported from Aydin and its surroundings since 1993. It is thought that the province has increasing importance in terms of public and veterinary health $(17,18)$. Therefore, the aims of this study were to determine the sand fly fauna, diversity and density of the species according to the altitudinal range and climatic factors, and to present the findings of the seasonal monitoring.

\section{METHODS}

\section{Study Area and Sand Fly Collections}

Aydın province (37.872208 E, 27.919010 N) located in Western Turkey has around one million inhabitants and surrounded by mountains in the South and North. Large fertile plains are located in the central and western parts of the province (Figure 1). The province experiences Mediterranean climate with hot and dry summers while winters are warm and rainy. The highest temperature is between $41.2{ }^{\circ} \mathrm{C}$ and $42.1{ }^{\circ} \mathrm{C}$ while the average temperature is between $27.2^{\circ} \mathrm{C}$ and $28.7^{\circ} \mathrm{C}$ in June and July. The average relative humidity is around $61 \%$ in Aydın province. The study was carried out in a transect from Aydın plain to the top of Aydın mountains, providing an altitudinal range between 65 and 1891 meters a.s.l.

The sand fly sampling was performed between June 16, 2009 and July 31, 2010 in every 15 days in July and August when sand flies are mostly active and every 30 days for the rest of the months using miniature CDC light traps (LTs) and sticky traps (STs). A total of 16 collections were done during the study period.

Although ACL and CanL have been reported from almost all settlements of the province (17), 10 villages were randomly selected for sand fly sampling on or around Aydin mountains according to the altitudinal range (two in each $200 \mathrm{~m}$ altitude range) (Figure 1). For setting up two CDC LTs, one closed points such as animal barns, poultries, dog shelters etc., and one open points outside per village were selected. The LTs were set up in the evening (17:00-18:00) at 1-1.5 meters above the ground and picked up early in the morning (06:00-07:00) for one night. In 
each sampling time, the LTs were placed in the same point as close as possible. Two LTs were placed in each village at 16 sampling times, and a total of 320 LTs were used during the entire study.

The geographical locations of each collection site were recorded using GPS, and a total seven data logger (HOBO) was placed together with LTs for measuring temperature and humidity in the microenvironmental level and left there for one year. The data loggers were programmed to record temperature/humidity every one hour starting from June 16, 2009. Additionally, other environmental parameters such as the number of animals in the location, physical features of the structure and vegetation were also recorded.

A4 sized regular papers were coated with castor oil to be used as STs and according to the suitability of the location, 10-30 STs per village were placed overnight in outdoor (wall cracks, drainage holes on the walls, etc.) and indoor (barns, houses, etc.) in each collection time. Sand flies were collected from a total of 2240 STs during the study. The STs collected were calculated in square meters to provide standardization while examining the species distribution based on the altitude.

The sand fly specimens were collected from the cages of LTs using a mouth aspirator and from STs using a fine brush dipped in $70 \%$ alcohol. After collection the specimens were stored in $96 \%$ ethanol for morphological identification. The specimens were individually prepared under the stereomicroscope (Olympus

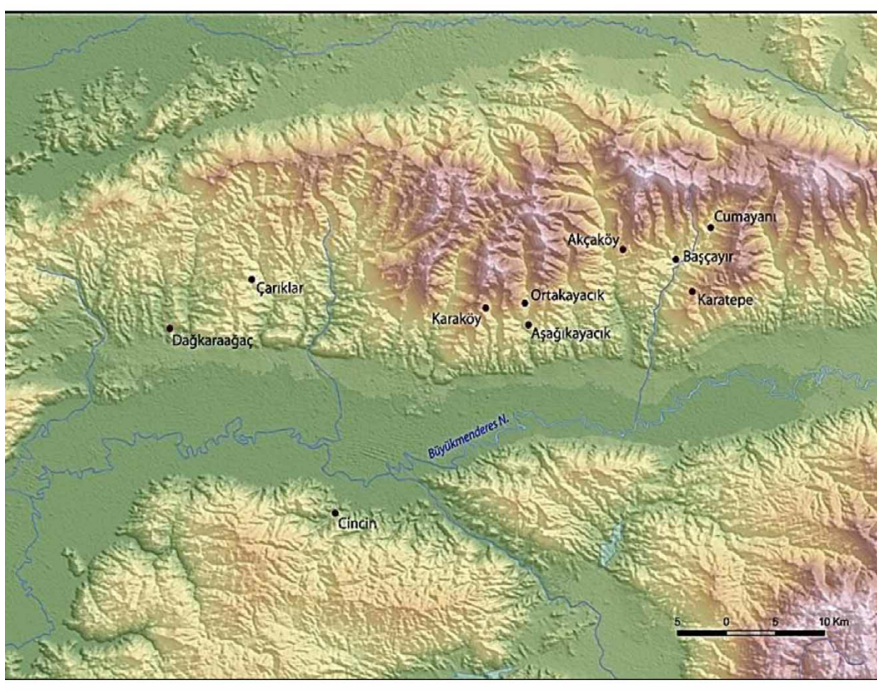

\begin{tabular}{|c|c|c|c|}
\hline Village (Locality) & \begin{tabular}{|c|}
$\begin{array}{c}\text { Altitude } \\
\text { (m) }\end{array}$ \\
\end{tabular} & $\begin{array}{l}\text { Altitudinal } \\
\text { range }(\mathrm{m})\end{array}$ & \begin{tabular}{|l|} 
Coordinates \\
Lat/Long \\
\end{tabular} \\
\hline Karatepe & 840 & $800-1000$ & $375547 \mathrm{~N} / 280512 \mathrm{E}$ \\
\hline Karaköy & 830 & $800-1000$ & $375455 \mathrm{~N} / 275349 \mathrm{E}$ \\
\hline Akçaköy & 780 & $600-800$ & $375759 \mathrm{~N} / 280123 \mathrm{E}$ \\
\hline Ortakayacık & 655 & $600-800$ & $375510 \mathrm{~N} / 275558 \mathrm{E}$ \\
\hline Cumayanı & 574 & $400-600$ & $375907 \mathrm{~N} / 280613 \mathrm{E}$ \\
\hline Çarıklar & 454 & $400-600$ & $375624 \mathrm{~N} / 274053 \mathrm{E}$ \\
\hline Aşağıkayacık & 376 & $200-400$ & $375402 \mathrm{~N} / 275610 \mathrm{E}$ \\
\hline Başçayır & 340 & $200-400$ & $375727 \mathrm{~N} / 280418 \mathrm{E}$ \\
\hline Dağkaraağaç & 107 & $0-200$ & $375351 \mathrm{~N} / 273623 \mathrm{E}$ \\
\hline Cincin & 75 & $0-200$ & $374410 \mathrm{~N} / 274530 \mathrm{E}$ \\
\hline
\end{tabular}

Figure 1. The location of the selected villages for sand fly collection and altitudes
SZ40) and the head and genitalia were cut, clarified in MarcAndre solution and mounted in swan solution then examined under the light microscope (Olympus CX31). Specimens were morphologically identified based on male external genitalia and female spermatheca and pharyngeal armature/cibarial armature using the several published written keys for Mediterranean sand flies (10,19-23).

\section{Data Analysis}

The seasonal activity and dominancy of sand fly species were calculated on monthly and yearly counts. The temperature and humidity data were extracted from seven data loggers and analyzed at the end of the study. The lowest and highest temperature/humidity values in the entire working time of the data loggers and the averages of temperature/humidity during collection days were evaluated.

Shannon-Wiener species diversity index and Evenness degree were used to estimate species diversity and distribution of individuals among all species to identify species diversity grade as a numerical value and to make statistical comparison of diversity grades in different localities (24).

"Kendal's Tau b" correlation measure was used to determine the relationship between the seasonality of different species and temperature/humidity. In this test, the correlation coefficient varies between $(-1)$ and $(+1)$. While the positive correlation indicates that the rows of both variables increase together, the negative correlation coefficient means that the number of rows of one variable increase while the number of rows of the other decreases. The correlation coefficient between 0 and 0.49 is interpreted as a weak relationship, a value between 0.50 and 0.69 is a medium relationship, and a value between 0.70 and 1 is interpreted as a high relationship.

\section{RESULTS}

\section{Sand Fly Fauna}

A total of 2.783 and 3.929 sand fly specimens were caught using CDC LTs and STs, respectively. Among these 6.712 specimens, 3.268 were female and 3.444 were male, which makes the female/ male ratio as 0.95 during all study periods. Nine and three species belonging to Phlebotomus and Sergentomyia genera were recorded in the study area, respectively. Among these, . major s.l. was the most abundant species with 2.039 (30.38\%) specimens, followed by $S$. dentata $(\mathrm{n}=1555 ; 23.17 \%)$ and $P$. tobbi $(\mathrm{n}=1539 ; 22.93 \%)$ (Table 1).

Three species P. major s.l., P. tobbi and P. sergenti s.l. were recorded from all villages and altitudes in both trapping methods. $P$. papatasi, was the fourth most widespread species but with a smaller number of specimens (Figure 2).

\section{Seasonal Dynamics of Sand Fly Species}

Most of sand fly specimens were collected between JuneSeptember. On the other hand, only one specimen (by sticky trap) in November, two specimens in February and one specimen (by CDC light trap) in March were found while no specimens were obtained in December and January. It was observed that April is the time when sand flies first start to emerge. The peak started in June with 982 specimens and continued in July with 1.014 specimens (Figure 3). The analysis of seasonal activities of all sand fly species revealed that only four Phlebotomus (P. alexandri, 


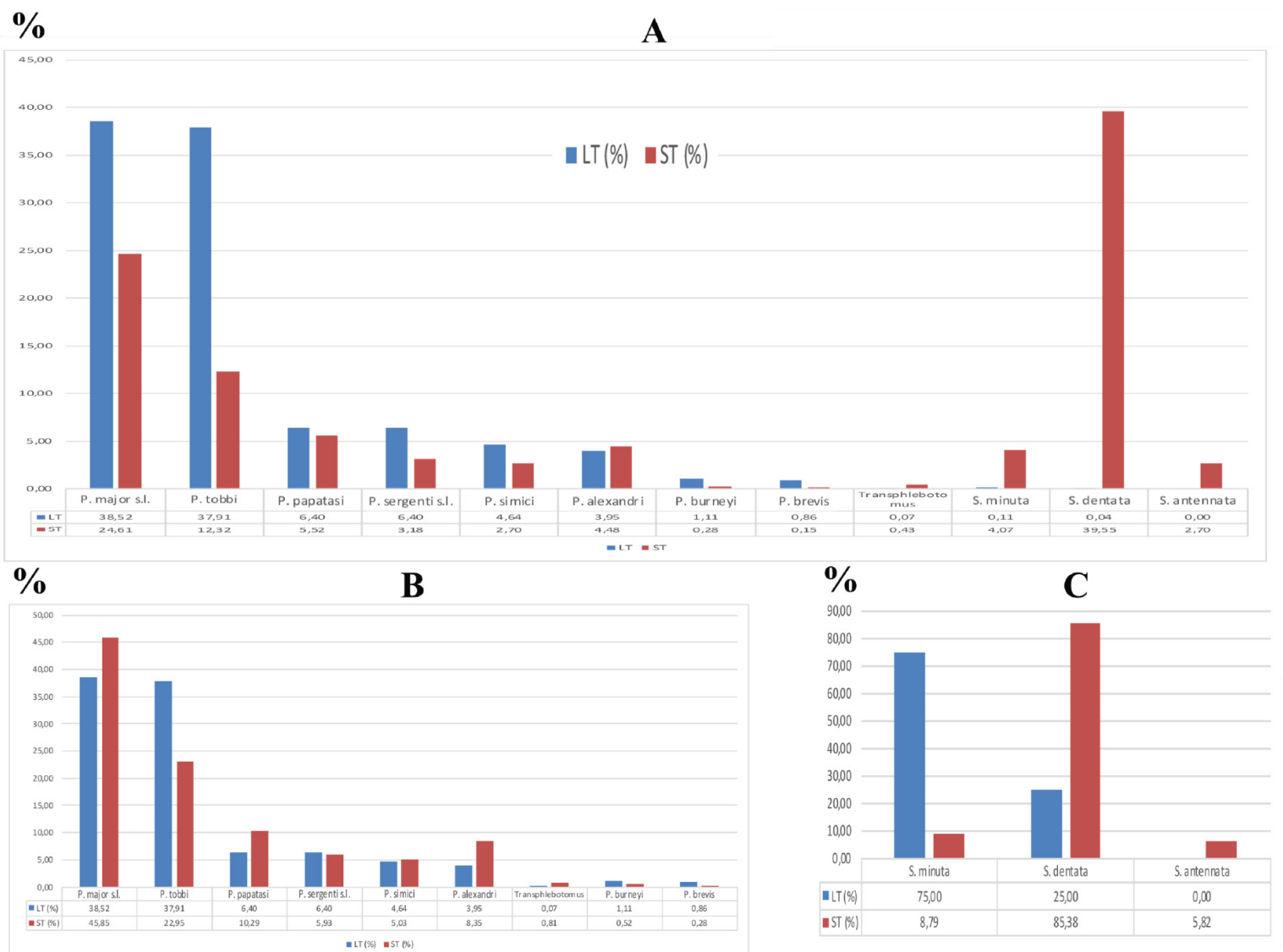

Figure 2. Sand fly composition of the study area. A. All sand fly species, B. Phlebotomus species ( $\mathrm{n}=4888)$; C. Sergentomyia species $(\mathrm{n}=1824)$

LT: Light traps. ST: Sticky traps. Specimens caught using LT (n=2783) and ST (n=3929) were evaluated separately for the graph

P. burneyi, P. simici, P. brevis) and one Sergentomyia (S. dentata) species have three peaks while the others have two peaks in the season. 'The features of seasonal activity of vector sand fly species are given in Table 2 and Figure 4. The seasonal activity of other sand fly species is given as supplemental data (Suppl File 1).

\section{Altitudinal Distribution}

Seventy percent and $48 \%$ of total specimens were caught at an altitudinal range of $200-400 \mathrm{~m}$ by CDC LTs and STs, respectively (Table 3). Additionally, around $50 \%$ of the specimens were caught at an altitude of $800-1000 \mathrm{~m}$ by sticky traps, and 1,552 (40\%) and
$307(7.8 \%)$ of the specimens were identified as S. dentata and P. major s.l., respectively. At the same altitudinal range (800-1000 m), 176 (6.3\%) P. major s.l. were caught using CDC LTs, however, no Sergentomyia specimens were found. All sand fly species were analyzed according to the altitudinal range and the results are given in Suppl File 2.

When the collection locations were evaluated according to altitude groups, statistically no relationship was observed between the number of individuals caught and temperature (Kendall $\tau, \mathrm{p} \geq 0.05$ ) and humidity (Kendall $\tau, \mathrm{p} \geq 0.05$ ).

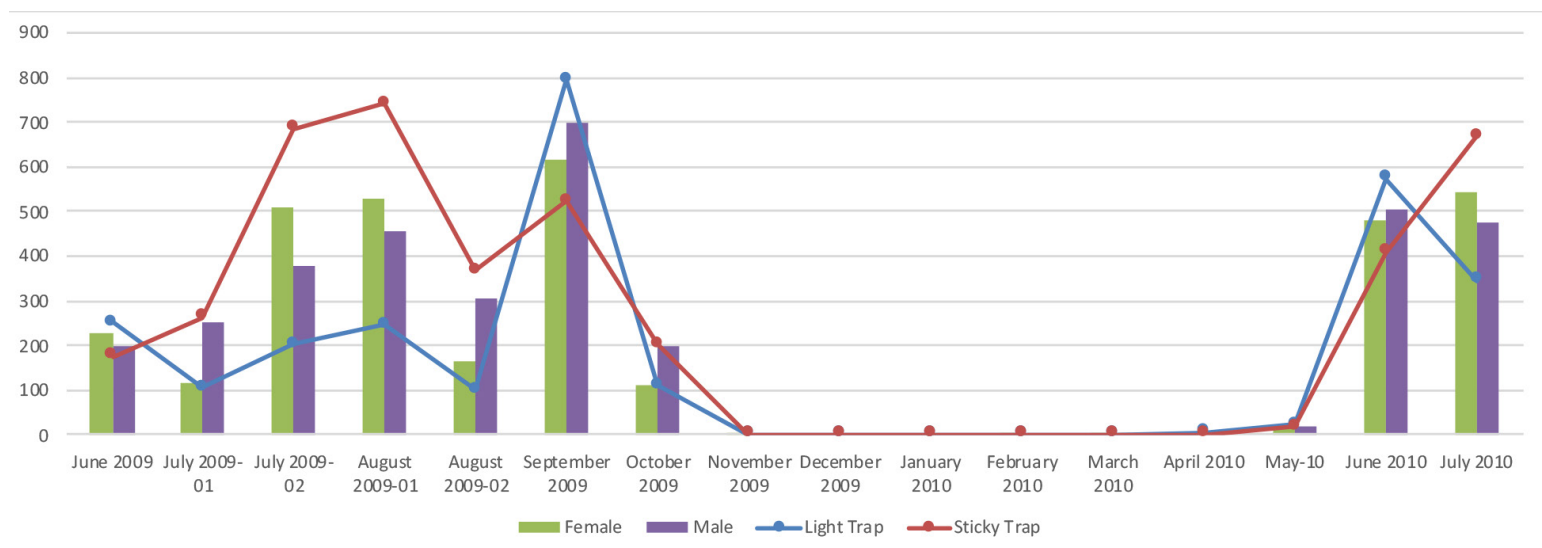

Figure 3. Seasonal distribution of the total sand fly specimens collected in 16 sampling periods by months between June 2009 and July 2010 
We also investigated whether there was a statistical difference between the number of sand flies caught depending on the altitude, and we observed that there were differences both among sand fly species and in the total number of specimens according to the altitude (Kruskal-Wallis test, $\mathrm{p} \leq 0.05$ ) (Figure 5, 6).

\section{Diversity Index}

The analyzes of the diversity index showed that $P$. sergenti s.l., $P$. major s.l. and P. tobbi was present in all localities, and P. sergenti s.l.
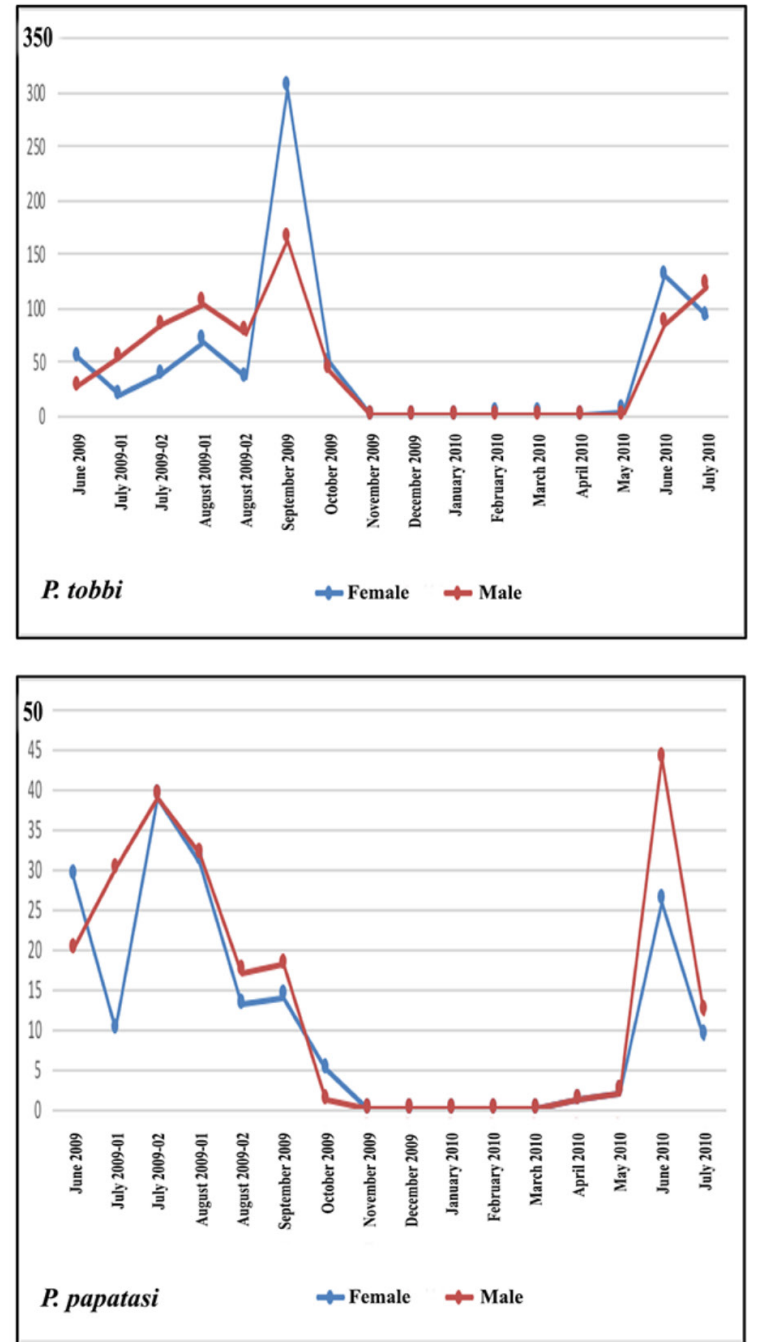

had the highest value according to the Shannon index. The highest species diversity was detected in Ortakayacık (655 m) village (Table 4). In addition, highest species diversity was recorded at the end of July compared to other collection times, according to Shannon index (Table 5).

Species diversity and species richness for the specimens collected by LTs were found high in the range of 600-800 m and 800-1000 $\mathrm{m}$, respectively. On the other hand, species diversity and species
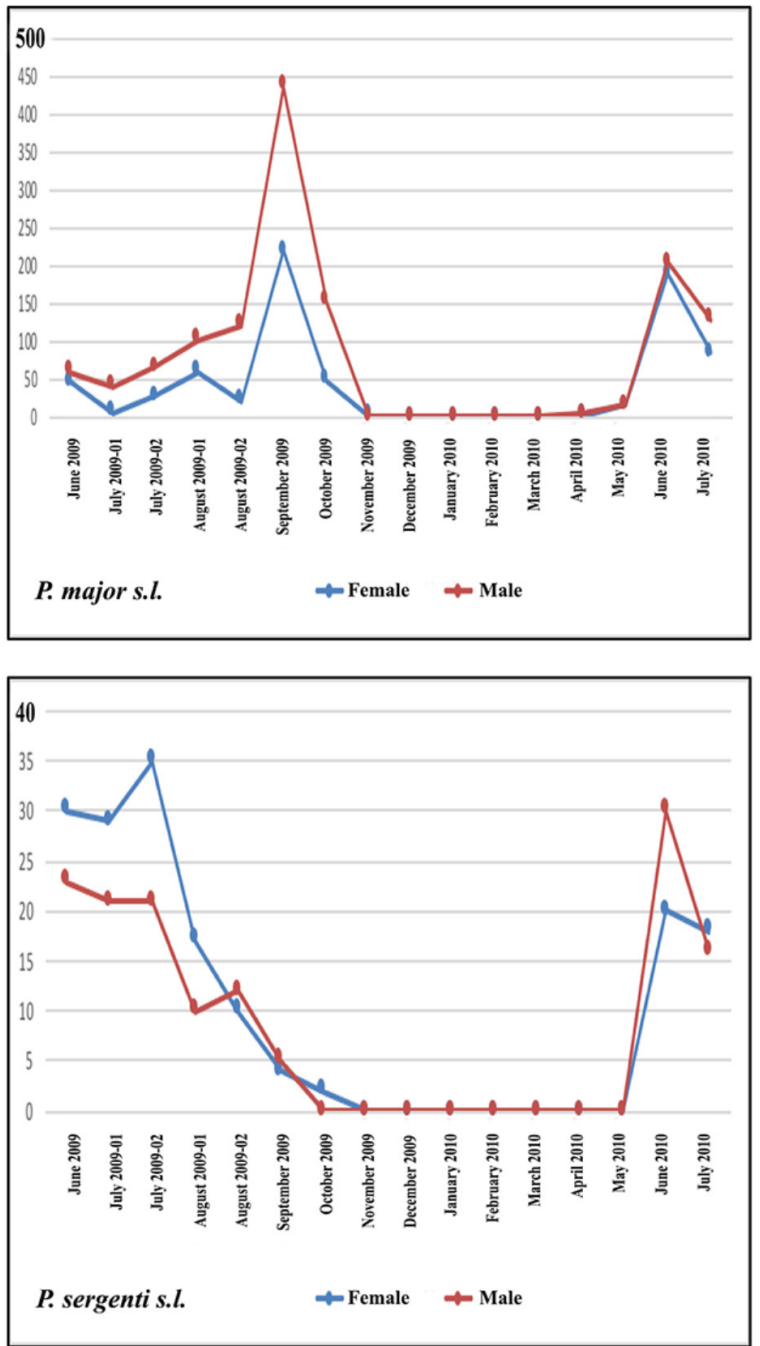

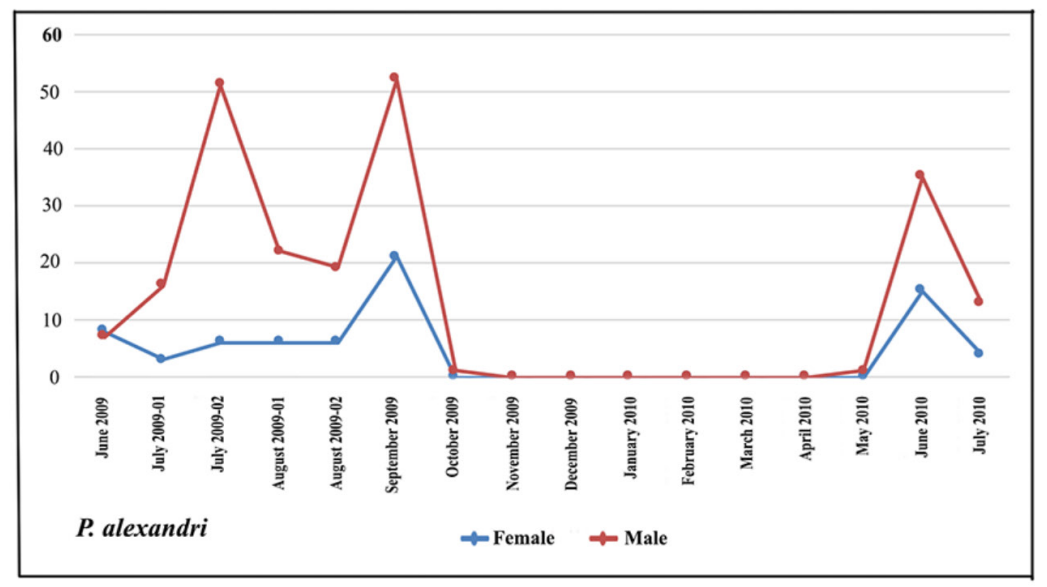

Figure 4. The seasonal distribution of five probable vector species between June 2009 and July 2010 in the study area 


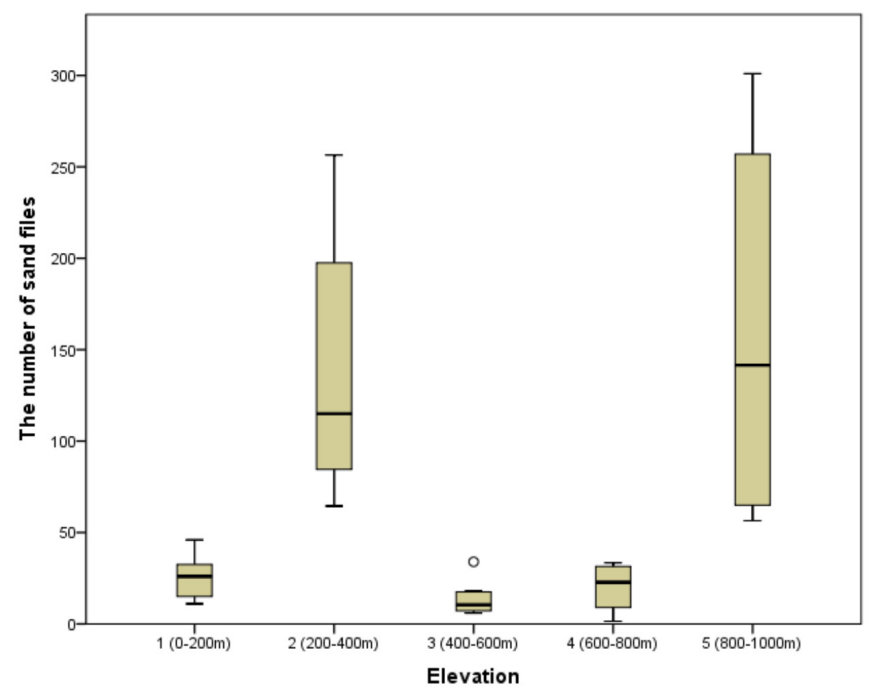

Figure 5. Total number of sand flies caught according to the altitude

richness for the samples collected by STs were found high in the range of 400-600 $\mathrm{m}$ and 0-200 $\mathrm{m}$ by Shannon index (Table 6).

\section{The Values Obtained by Data Loggers}

The temperatures were detected as between 16.6 and $20.6{ }^{\circ} \mathrm{C}$ (ave $18.7^{\circ} \mathrm{C}$ ), and $\mathrm{RH} \%$ were between $54.1-60.9 \%$ (ave $58.0 \%$ ) according to the locations. The values extracted from data loggers showing minimum, maximum and average temperature and humidity in the seven localities were given in Figure 7. According to the data obtained from data loggers, during the months of June-September, between 10:00 and 03:00 at night when sand flies are most active, the average temperature and humidity in localities was $23.1-26.2{ }^{\circ} \mathrm{C}$ (min-max) and 43.5-47.7\% (min-max) respectively. The temperature and humidity values obtained from the data loggers placed in the localities were also evaluated according to the non-parametric Kendall's Tau b correlation coefficient. A medium positive relationship was found between the presence of three species [P. papatasi (0.52), P. major s.l. (0.51), P. tobbi (0.51)] and temperature, but other Phlebotomus species showed weak positive relationships (>0.49) with temperature. On the other hand, a weak negative relationship ( $>0.42)$ was detected between the presence of the species and humidity.

\section{DISCUSSION}

In the leishmaniasis endemic areas, the detection of sand fly species and their distribution provides essential knowledge to understanding the transmission dynamics of different clinical forms of leishmaniasis. In addition, the data about the seasonal activity of sand fly vectors improves knowledge for better decision making on appropriate time periods for application of vector control measures in different endemic areas. Aydın province and its surroundings, is one of the important endemic areas for ACL and CanL in the western part of Turkey. In the present study, we aimed to provide new data on seasonal activity of sand fly species in the area in relation to altitude and microclimatic data. To this aim, detailed analyses after the morphological identification of sand flies obtained from 16 collections between June 2009 and July 2010 in the selected 10 villages were carried out.

A total of 12 sand fly species (9 Phlebotomus, 3 Sergentomyia) were identified in the study. The ratios of sand fly specimens belonging to Phlebotomus and Sergentomyia genera were $72.82 \%$ and $27.18 \%$, respectively. Phlebotomus specimens were mainly found in the areas where humans and animals live while Sergentomyia species were mostly caught by STs in stony areas such as stone walls where many reptiles were observed. In previous studies conducted in Turkey, it is emphasized that the populations of species belonging to the genus Sergentomyia are generally less. Although the number of Sergentomyia species collected were less than the Phlebotomus, the number of individuals was found to be significantly higher than in previous studies (25-28). The reason for this is thought to be due to the researchers placing traps more on the animal barn or areas where people live, and generally using only the LTs. As we applied in the present study, the usage of LTs and STs

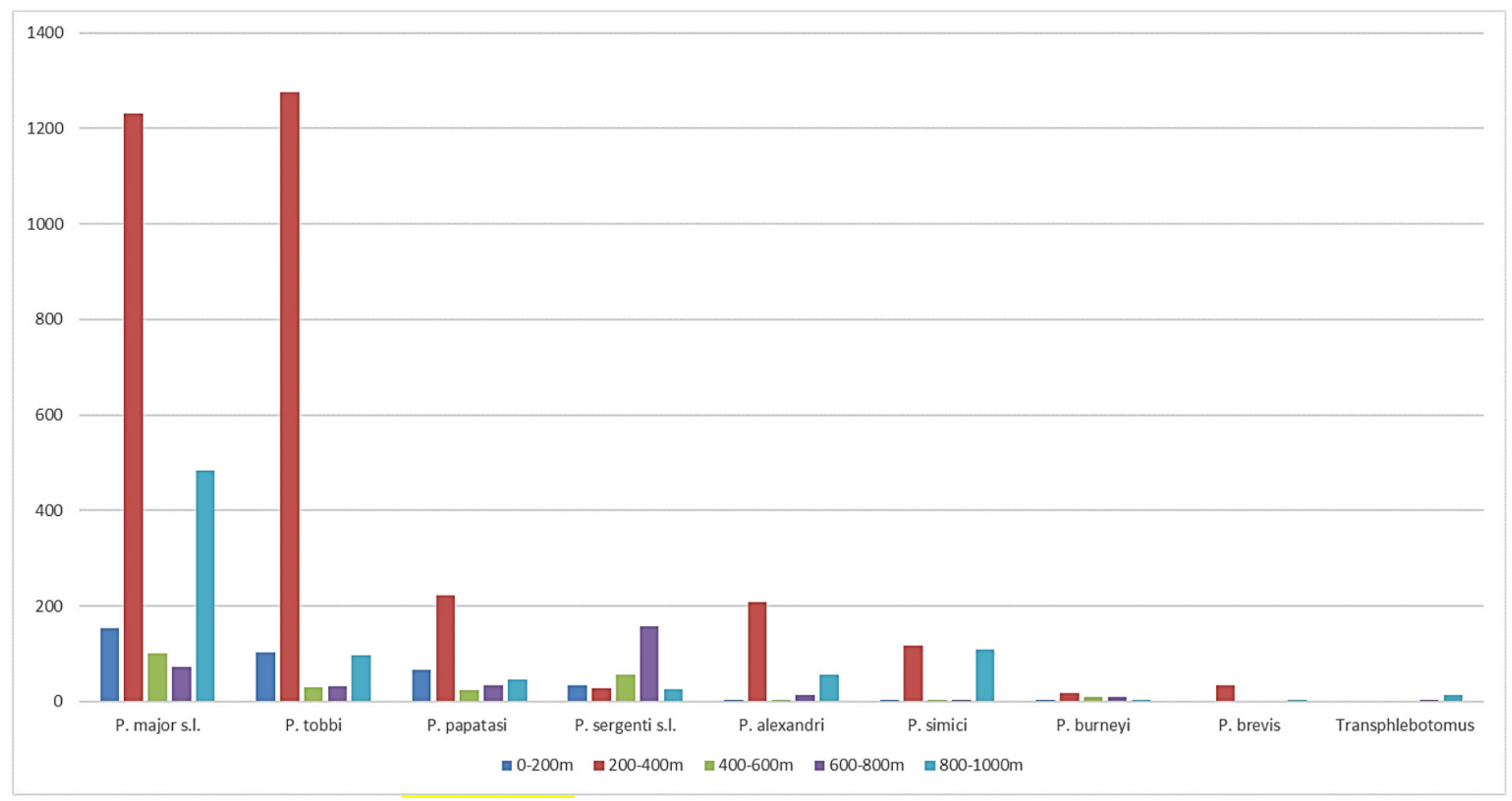

Figure 6. The distribution of Phlebotomus species found in all altitudinal ranges 


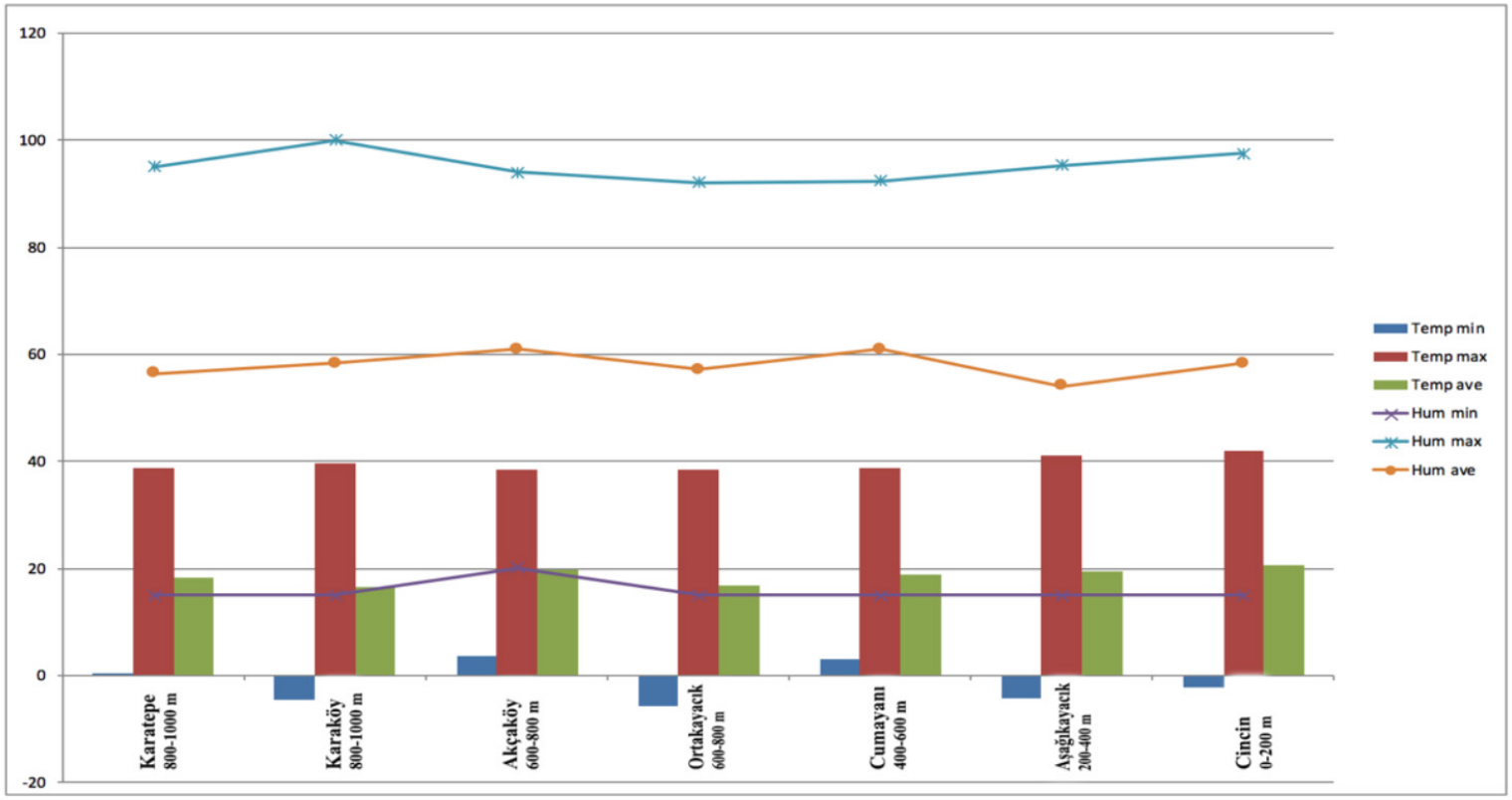

Figure 7. Temperature and humidity data obtained from data loggers

together has also an advantage not only to catch all sand fly species belonging to both genera in the area but also to perform quantitative analyses.

Phlebotomus tobbi (22.93\%) is the proven vector species of $L$. infantum in the eastern part of the Mediterranean Region of Turkey and P. major s.l. (30.38\%), a well-known vector species of L. infantum in Europe and Turkey, were found as the dominant species. P. jacusieli, P. perfiliewi and $S$. theodori species, previously found in Aydin province (18), were not encountered in the present study, however, $S$. antennata were not reported in the previous studies. This probably happens due to the morphological similarity of three Sergentomyia species present in Turkey. Beside these species, other proven or probable vector species of different Leishmania parasites, P. papatasi, P. sergenti s.l., and P. alexandri (29), were found in the study area. In addition, all species caught during the present study have also been reported previously in the different provinces of Turkey (16,18,26-28,30-33).

Almost $68 \%$ and $90 \%$ of P. major s.l. and P. tobbi were collected in the $0-400 \mathrm{~m}$ altitudinal range by both types of traps, respectively. Additionally, $24 \%$ of $P$. major s.l. specimens were caught in the 800 $1000 \mathrm{~m}$ altitudinal range. When we checked the ACL cases in Aydin province between 2006 and 2014, we have found that 251 ACL cases were reported in this period and $85.25 \%(n=214)$ of them were from rural settlements located in between 40 and 400 meters. Only 16 (6.4\%) ACL cases were reported from the settlements located above $600 \mathrm{~m}$ in the area (Özbel Y-unpublished data). A previous study analyzing the Leishmania isolates from different provinces reported the presence of only L. tropica $(n=63)$ in Aydin province (15). Because of this report and altitudinal distribution of ACL cases as mentioned above, we also evaluated our findings related to $P$. sergenti s.l. and we have seen that the vector species of L. tropica, P. sergenti s.l., was detected at all altitudes, but half (52\%) were found in the $600-800 \mathrm{~m}$ range. These previous and present findings emphasize the complication of the situation in the area in terms of leishmaniasis. There is a need to check much more ACL clinical samples (lesion aspiration fluids, biopsies) instead of isolates by molecular methods for species identification to understand the causative agent(s) in the area clearly. Because of the lack of records about locations of Leishmania infected dogs, it is difficult to analyze CanL situation in this endemic area.

Studies related to sand flies carried out in Turkey showed that climatic and microenvironmental specifications together with altitude are main factors affecting sand fly species distribution and abundance $(28,34,35)$. In our study, we also determined that there are differences according to the total number of species and the altitude among the sand fly species caught. In addition, we realized that this difference is not a gradual decrease or increase. We observed that the temperature and humidity did not change significantly according to the locations in different altitudinal ranges (Figure 7). This is also reflected in the species diversity detected in the locations ( $\min 8$; max 12 species). For this reason, and probably related to other abiotic factors, such as geographical specifications of the study area, vegetation and soil type, we could not find a strong relationship between temp/ hum and species diversity. On the other hand, the population size of the three vector species was significantly higher (Table 1) at the altitude of $200-400 \mathrm{~m}$ where the average temperature $19.6{ }^{\circ} \mathrm{C}$ and average humidity $54.1 \%$. Therefore, we can conclude that the number of sand flies caught in the study area may be related to the microhabitat conditions (e.g., olive trees in lower and fig trees in higher altitudes) in the environment rather than or together with the altitude.

P. neglectus and P. syriacus, which are morphologically similar species in $P$. major group, have been reported as separate species in many faunistic studies. It has been stated that $P$. syriacus can be found in the south of Turkey while P. neglectus can be found in all geographical regions (36). However, since both of them belong to the P. major group and molecular analyzes were not performed in the present study, we preferred to report it as P. major s.l. Most of the Larroussius species are proven vectors of L. infantum in Southern Europe, Southwest Asia and North Africa $(29,31)$. Phlebotomus neglectus has been reported as a vector of $L$. infantum causing VL in Greece (37), Croatia (38) and Italy (39). It has also been stated that 
Table 1. Distribution of sand fly species according to 10 villages of the Aydın Mountains and surroundings

\begin{tabular}{|c|c|c|c|c|c|c|c|c|c|c|c|c|c|c|}
\hline \multirow[b]{2}{*}{$\begin{array}{l}\text { Villages } \\
\text { (altitudem) }\end{array}$} & \multirow[b]{2}{*}{$\begin{array}{l}\text { Trap } \\
\text { type }\end{array}$} & \multicolumn{13}{|c|}{ Sand fly species } \\
\hline & & 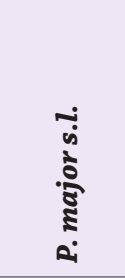 & 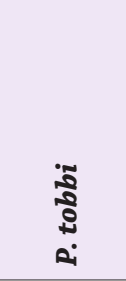 & 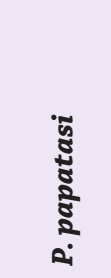 & 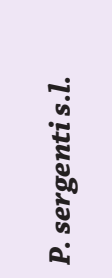 & 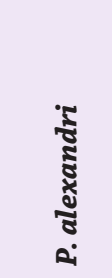 & 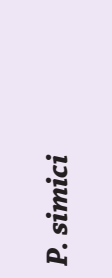 & 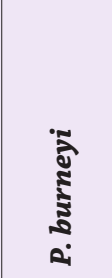 & 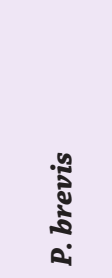 & 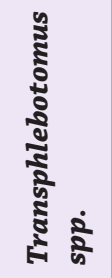 & 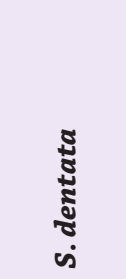 & 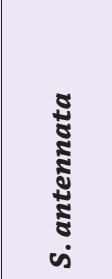 & 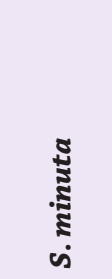 & Total \\
\hline \multirow{2}{*}{$\begin{array}{l}\text { Cincin } \\
(75 \mathrm{~m})\end{array}$} & $\mathbf{L T}$ & 8 & 18 & 8 & 2 & 0 & 0 & 2 & 0 & 0 & 0 & 0 & 1 & 39 \\
\hline & ST & 59 & 59 & 6 & 27 & 1 & 1 & 1 & 1 & 0 & 0 & 0 & 49 & 204 \\
\hline \multirow{2}{*}{$\begin{array}{l}\text { Dağkaraağaç } \\
(\mathbf{1 0 7} \mathbf{~ m})\end{array}$} & LT & 62 & 21 & 19 & 4 & 1 & 0 & 0 & 0 & 0 & 0 & 0 & 1 & 108 \\
\hline & ST & 25 & 6 & 34 & 1 & 1 & 2 & 0 & 0 & 0 & 0 & 0 & 1 & 70 \\
\hline \multirow{2}{*}{$\begin{array}{l}\text { Başçayır } \\
\text { (340 m) }\end{array}$} & LT & 557 & 642 & 33 & 7 & 78 & 39 & 11 & 11 & 0 & 1 & 0 & 1 & 1380 \\
\hline & ST & 505 & 261 & 25 & 3 & 111 & 26 & 1 & 2 & 0 & 0 & 0 & 0 & 934 \\
\hline \multirow{2}{*}{$\begin{array}{l}\text { Aşağıkayacık } \\
(376 \mathrm{~m})\end{array}$} & LT & 137 & 302 & 65 & 9 & 11 & 31 & 4 & 12 & 0 & 0 & 0 & 0 & 571 \\
\hline & ST & 31 & 70 & 100 & 10 & 9 & 21 & 1 & 0 & 2 & 0 & 0 & 1 & 245 \\
\hline \multirow{2}{*}{$\begin{array}{l}\text { Çarıklar } \\
\text { (454 m) }\end{array}$} & $\mathbf{L T}$ & 17 & 15 & 4 & 19 & 1 & 0 & 6 & 0 & 0 & 0 & 0 & 0 & 62 \\
\hline & ST & 5 & 3 & 16 & 25 & 2 & 1 & 4 & 0 & 0 & 0 & 1 & 0 & 57 \\
\hline \multirow{2}{*}{$\begin{array}{l}\text { Cumayanı } \\
(574 \mathrm{~m})\end{array}$} & LT & 60 & 11 & 4 & 10 & 0 & 1 & 0 & 1 & 0 & 0 & 0 & 0 & 87 \\
\hline & ST & 18 & 1 & 1 & 2 & 1 & 1 & 0 & 0 & 0 & 1 & 0 & 2 & 27 \\
\hline \multirow{2}{*}{$\begin{array}{l}\text { Ortakayacik } \\
(655 \mathrm{~m})\end{array}$} & LT & 50 & 15 & 9 & 31 & 10 & 3 & 7 & 0 & 1 & 0 & 0 & 0 & 126 \\
\hline & ST & 0 & 1 & 0 & 11 & 0 & 0 & 1 & 0 & 2 & 0 & 0 & 0 & 15 \\
\hline \multirow{2}{*}{$\begin{array}{l}\text { Akçaköy } \\
\text { (780 m) }\end{array}$} & LT & 5 & 3 & 5 & 80 & 0 & 0 & 1 & 0 & 0 & 0 & 0 & 0 & 94 \\
\hline & ST & 17 & 14 & 20 & 36 & 4 & 0 & 0 & 0 & 0 & 1 & 0 & 0 & 92 \\
\hline \multirow{2}{*}{$\begin{array}{l}\text { Karaköy } \\
(830 \text { m) }\end{array}$} & LT & 42 & 6 & 0 & 6 & 0 & 1 & 0 & 0 & 0 & 0 & 0 & 0 & 55 \\
\hline & ST & 4 & 0 & 0 & 0 & 0 & 0 & 1 & 0 & 0 & 0 & 0 & 0 & 5 \\
\hline \multirow{2}{*}{$\begin{array}{l}\text { Karatepe } \\
(840 \text { m) }\end{array}$} & LT & 134 & 22 & 31 & 10 & 9 & 54 & 0 & 0 & 1 & 0 & 0 & 0 & 261 \\
\hline & ST & 303 & 69 & 15 & 10 & 47 & 54 & 2 & 3 & 13 & 1552 & 105 & 107 & 2280 \\
\hline \multirow{4}{*}{$\begin{array}{l}\text { Total } \\
\text { specimens by } \\
\text { trap type }\end{array}$} & LT & 1072 & 1055 & 178 & 178 & 110 & 129 & 31 & 24 & 2 & 1 & 0 & 3 & 2783 \\
\hline & LT \% & 38.52 & 37.91 & 6.40 & 6.40 & 3.95 & 4.64 & 1.11 & 0.86 & 0.07 & 0.04 & O & 0.11 & 100 \\
\hline & ST & 967 & 484 & 217 & 125 & 176 & 106 & 11 & 6 & 17 & 1554 & 106 & 160 & 3929 \\
\hline & ST \% & 24.61 & 12.32 & 5.52 & 3.18 & 4.48 & 2.70 & 0.28 & 0.15 & 0.43 & 39.55 & 2.70 & 4.07 & 100 \\
\hline TOTAL & & $\begin{array}{l}2039 \\
\mathbf{3 0 . 3 8 \%}\end{array}$ & $\begin{array}{l}1539 \\
\mathbf{2 2 . 9 3 \%}\end{array}$ & $\begin{array}{l}395 \\
\mathbf{5 . 8 8 \%}\end{array}$ & $\begin{array}{l}303 \\
\mathbf{4 . 5 1 \%}\end{array}$ & \begin{tabular}{|l}
286 \\
$\mathbf{4 . 2 6 \%}$
\end{tabular} & $\begin{array}{l}235 \\
\mathbf{3 . 5 0 \%}\end{array}$ & $\begin{array}{l}42 \\
\mathbf{0 . 6 3 \%}\end{array}$ & $\begin{array}{l}30 \\
\mathbf{0 . 4 5 \%}\end{array}$ & $\begin{array}{l}19 \\
\mathbf{0 . 2 8 \%}\end{array}$ & $\begin{array}{l}1555 \\
\mathbf{2 3 . 1 7 \%}\end{array}$ & $\begin{array}{l}106 \\
\mathbf{1 . 5 8 \%}\end{array}$ & $\begin{array}{l}163 \\
\mathbf{2 . 4 3} \%\end{array}$ & 6712 \\
\hline
\end{tabular}

LT: Light trap, ST: Sticky trap

in Turkey, the members of $P$. major group are probable vectors of L. infantum $(27,40)$. Phlebotomus major s.l. was found to be the dominant species in the study area with a rate of $30.38 \%$ $(\mathrm{n}=2039)$ in our study. Although this species is found in all villages, $52 \%$ of the specimens were collected from Başçayır village $(340 \mathrm{~m})$. In the studies conducted in Aydın province, Davies (41) found P. neglectus as the fourth dominant species with a rate of $12.66 \%$ using LTs while Özbel et al. (18) reported it as the second dominant species with a rate of $26.6 \%$ by STs. In our study, two peaks of this species recorded in June and September showed similarity with the results obtained in the study conducted in Çukurova plain, Adana province located in Eastern Mediterranean (33). In another study performed in the Greater region of Athens in 1992 P. neglectus had two peaks in June and October (42). While other species caught in the same area were showing a sharp decrease, $P$. neglectus had a peak in October which can be evaluated as an unusual finding for this geographical region.

P. tobbi, a confirmed vector of $L$. infantum in the world, has been reported from the countries in the Eastern Mediterranean (20), Eastern Europe, (43) and the Middle East (44). It was found from all geographical regions in Turkey, and in the studies conducted in the Adana province (Çukurova plain), it was detected as proven vector of $L$. infantum causing cutaneous leishmaniasis $C L$ in this endemic area (31). In other two studies also conducted in Adana province (Çukurova plain), P. tobbi was found to be dominant with rates of $67.48 \%$ (33) and $71.3 \%$ (28). In the present study, around $23 \%(\mathrm{n}=1539)$ of the total specimens collected were $P$. tobbi. Among 1.539 specimens collected by both types of traps, $59 \%$ and $24 \%$ of them were collected from two villages (Başçayır 
Table 2. Seasonal activity features of five probable vector species found in the study area

\begin{tabular}{|c|c|c|c|c|c|c|}
\hline Species & $\begin{array}{l}\text { Total } \\
\text { collections } \\
\text { n (\%) }\end{array}$ & $\begin{array}{l}\text { Active period } \\
\text { (from/to) }\end{array}$ & Seasonal peaks & $\begin{array}{l}\text { Month of } \\
\text { highest } \\
\text { density (\%) }\end{array}$ & $\begin{array}{l}\text { Female/male } \\
\text { ratio }\end{array}$ & $\begin{array}{l}\text { Altitudinal } \\
\text { range } \mathrm{m} \\
\text { (trap type) }\end{array}$ \\
\hline P. major s.l. & $\begin{array}{l}2039 \\
(30.38)\end{array}$ & April-November & $\begin{array}{l}2 \text { peaks } \\
\text { June \& } \\
\text { September }\end{array}$ & $\begin{array}{l}\text { September } \\
(32.27)\end{array}$ & 0.53 & $\begin{array}{l}\text { 200-400 } \\
\text { (LT\&ST) }\end{array}$ \\
\hline P. tobbi & $\begin{array}{l}1539 \\
(22.93)\end{array}$ & May-October & $\begin{array}{l}2 \text { peaks } \\
\text { June \& } \\
\text { September }\end{array}$ & $\begin{array}{l}\text { September } \\
(30.28)\end{array}$ & 1.05 & $\begin{array}{l}200-400 \\
(L T \& S T)\end{array}$ \\
\hline P. papatasi & $\begin{array}{l}395 \\
(5.88)\end{array}$ & April-October & $\begin{array}{l}2 \text { peaks } \\
\text { June \& end of } \\
\text { July }\end{array}$ & July (19.75) & 0.82 & $\begin{array}{l}200-400 \\
(L T \& S T)\end{array}$ \\
\hline P. sergenti s.l. & $\begin{array}{l}303 \\
(4.51)\end{array}$ & June-October & $\begin{array}{l}2 \text { peaks } \\
\text { June \& end of } \\
\text { July }\end{array}$ & July (18.48) & 1.19 & $\begin{array}{l}\text { 600-800 } \\
\text { (LT\&ST) }\end{array}$ \\
\hline
\end{tabular}

Table 3. The percentages of total sand flies caught according to the trap type in different altitudinal range

\begin{tabular}{|l|l|l|l|l|}
\hline $\begin{array}{l}\text { Altitude } \\
(\mathbf{m})\end{array}$ & $\begin{array}{l}\text { Light trap } \\
(\mathbf{\%})\end{array}$ & $\begin{array}{l}\text { Sticky trap } \\
(\mathbf{\%})\end{array}$ & $\begin{array}{l}\text { Sticky trap } \\
\text { (total specimens/m }\end{array}$ & $\begin{array}{l}\text { No of species found by both } \\
\text { type of traps }\end{array}$ \\
\hline $0-200$ & 5.23 & 7.88 & 8.99 & 8 \\
\hline $\mathbf{2 0 0 - 4 0 0}$ & $\mathbf{6 9 . 7 1}$ & $\mathbf{4 8 . 2 7}$ & $\mathbf{5 5 . 0 7}$ & $\mathbf{1 1}$ \\
\hline $400-600$ & 5.41 & 3.93 & 4.48 & 11 \\
\hline $600-800$ & 8.17 & 4.82 & 5.5 & 9 \\
\hline $800-1000$ & 11.49 & 35.10 & 40.04 & 12 \\
\hline
\end{tabular}

Table 4. Species diversity according to the villages at different altitude

\begin{tabular}{|l|l|l|l|l|l|}
\hline Villages & Altitude $(\mathbf{m})$ & No of species & No of specimens & Shannon_H & Shannon_E \\
\hline Cincin & 75 & 9 & 243 & 1.58 & 0.54 \\
\hline Dağkaraağaç & 107 & 7 & 178 & 1.24 & 0.49 \\
\hline Başçayır & 340 & 10 & 2314 & 1.20 & 0.33 \\
\hline Aşağ1kayacık & 376 & 10 & 816 & 1.47 & 0.43 \\
\hline Çarıklar & 454 & 8 & 119 & 1.64 & 0.64 \\
\hline Cumayanı & 574 & 9 & 141 & 1.13 & 0.34 \\
\hline Ortakayacık & 655 & 8 & 186 & $\mathbf{1 . 6 6}$ & 1.17 \\
\hline Akçaköy & 780 & 7 & 60 & 0.66 & 0.46 \\
\hline Karaköy & 830 & 5 & 2541 & 1.35 & 0.44 \\
\hline Karatepe & 840 & 12 & & 0.32 \\
\hline
\end{tabular}

and Aşağıkayacık) located in 200-400 m altitudinal range. In the studies conducted in Aydın province, Davies (41) found P. tobbi as dominant species with a rate of $28.66 \%$ by LTs while Özbel et al. (18) reported it as the third dominant species with the ratio of $12.1 \%$ by STs. In Çukurova plain, sand fly activity starts in the beginning of May and ends in October. Phlebotomus tobbi and other sand fly species reach two peaks in August and September, and most of P. tobbi specimens were collected in 100-199 m altitudinal range (33). In our study region, we observed two peaks in June and September while the activity period was similar to the previous study (33) that is probably due to similar climate and altitudinal range.
P. sergenti and $P$. similis are sister species that are showing allopatric distribution in Old World countries. Significant morphological variation has been reported among $P$. sergenti populations found in Old World countries, and both species have been reported only in Turkey with differences in their distribution areas. Phlebotomus sergenti and $P$. similis are previously reported as proven vector species of L. tropica in the southeastern and western parts of Turkey, respectively $(18,26,45)$. Phlebotomus similis is found in Europe in Greece (46) and Albania (47) and is thought to be a potential vector of ACL. However, in a study conducted with molecular barcoding (cox1 gene region), it was stated that none of the P. sergenti samples examined in western Turkey matched 
Table 5. Species diversity of caught sand flies according to the collection months

\begin{tabular}{|l|l|l|l|l|}
\hline Months & $\begin{array}{l}\text { No of } \\
\text { species }\end{array}$ & $\begin{array}{l}\text { No of } \\
\text { specimens }\end{array}$ & Shannon_H & Shannon_E \\
\hline June 2009 & 11 & 414 & 1.88 & 0.59 \\
\hline July 2009 & 12 & 350 & $\mathbf{2 . 1 8}$ & $\mathbf{0 . 7 4}$ \\
\hline July 2009 & 12 & 874 & 1.74 & 0.47 \\
\hline $\begin{array}{l}\text { August } \\
\text { 2009 }\end{array}$ & 10 & 974 & 1.65 & 0.52 \\
\hline $\begin{array}{l}\text { August } \\
\text { 2009 }\end{array}$ & 12 & 459 & 1.86 & 0.53 \\
\hline $\begin{array}{l}\text { September } \\
\text { 2009 }\end{array}$ & 11 & 1304 & 1.20 & 0.30 \\
\hline $\begin{array}{l}\text { October } \\
\text { 2009 }\end{array}$ & 9 & 304 & 0.89 & 0.27 \\
\hline April 2010 & 2 & 7 & 0.59 & $\mathbf{0 . 9 0}$ \\
\hline May 2010 & 6 & 41 & 1.02 & 0.46 \\
\hline June 2010 & 12 & 973 & 1.78 & 0.49 \\
\hline July 2010 & 11 & 1009 & 1.60 & 0.45 \\
\hline
\end{tabular}

the samples obtained from Crete, therefore, the existence of previously reported $P$. similis species is controversial (36). Since molecular analyzes were not performed in this study, we preferred to report it as P. sergenti s.l. Phlebotomus sergenti s.l. was found in all localities in our study, it constituted $4.51 \%(n=303)$ of the total species collected from the study area, and it was recorded in Akçaköy $(780 \mathrm{~m}$ ) locality with a maximum abundance of $38 \%$ $(\mathrm{n}=116)$. While Davies (41) reported this species as $P$. similis with a rate of $5.65 \%$, and Özbel et al. (18) reported it as dominant species (20.33\%) and evaluated it as a possible vector of L. tropica in the same area. This species showed two peaks in June and the end of July in the study area. In any case, the detection of this species in all localities in the study area was considered as a finding of increased transmission risk of the parasite in these areas.

The anthropophilic species $P$. alexandri showing wide distribution from Spain to China and Africa (7) is a confirmed or probable vector species of $L$. donovani and L. infantum in China (48) and Iran (49), respectively. In Turkey, this species was previously notified from almost all VL and CL endemic areas where fauna studies were performed (18), but it is dominant species only in one CL endemic town, Silifke in Mersin Province (50). Phlebotomus alexandri remains an important species as a probable vector species of $L$. donovani in Turkey especially after detecting CL and VL cases caused by L. donovani in Turkey (51). Phlebotomus alexandri was found with the ratio of $1.1 \%(n=6)$ by STs in this area previously (18). In the present study, we collected 110 and 176 specimens
(4.26\%) by light and STs, respectively. The dominancy ( $\mathrm{n}=189)$ was detected in Başçayır village located in $340 \mathrm{~m}$ a.s.l. Most of leishmaniasis vectors detected in the present study showed two peaks in June/July and September while only P. alexandri showed three peaks in June, the end of July and September.

The certain vector of ZCL, P. papatasi has the widest geographical distribution among Old-World sand fly species (45). It has also wide distribution throughout Turkey (https://www.kisa.link/ PfvY) with dominancy in a highly endemic area of ACL, Şanliurfa province $(26,30)$. In the present study, we found this species in all altitude ranges with a total of 395 (5.88\%) specimens. It is showed two peaks in June and the end of July in our study area. The seasonal activity of $P$. papatasi was also investigated in one $\mathrm{CL}$ and one VL endemic area. While the Mediterranean climate seen in Çukurova CL endemic areas and has an average altitude of 200-250 m, is similar to our study area, a completely different continental climate is observed in Kars province in a VL endemic area having $2000 \mathrm{~m}$ average altitude. It has been determined that the seasonal activity of $P$. papatasi has one or two peaks between June and September in different localities in Çukurova $(32,33)$. On the other hand, due to the short active season of sand flies in Kars province, P. papatasi had peaked only in August (52). In a meta-analysis examining 36 studies published between 1994 and 2017 on the seasonal activity of P. papatasi conducted in 61 localities in 15 countries in the Old World, it was found that the seasonal activity begins in May and peaks two times between June and September in almost all of these countries. It is stated that three peaks are observed in some localities in the Middle East countries where the active season lasts longer due to the favorable temperature (53). In our study area, it was observed that P. papatasi had two peaks in the middle of June and at the end of July. Sand fly fauna studies showed the presence of $P$. papatasi in almost all $\mathrm{CL}$ endemic areas of Turkey. For this reason, the distribution and nocturnal/seasonal activity of $P$. papatasi are now more important for Turkey in relation to the increasing autochthonous CL cases caused by L. major.

Diversity indices for sand flies have been used by many researchers $(28,33,54)$. Diversity index was also used in our study, and the results showed that although P. major s.l. $(\mathrm{n}=2039)$ was the dominant species, P. sergenti s.l., a possible vector of CL in the area, was more evenly distributed in Aydın Province than other species. The Shannon-Wiener index $(\mathrm{H})$ indicated no high significant difference between the diversity and abundance of sand fly species distribution in different altitudes (Table 6). Evenness degree and species diversity reached maximum values at $800-1000 \mathrm{~m}$ and 0-200 m by light and sticky trap collections, respectively.

Phlebotomus sergenti s.l., P. major and P. tobbi were found in all localities. Karatepe village $(840 \mathrm{~m})$ where all 12 species were

Table 6. Species diversity according to the altitudinal range by both types of traps

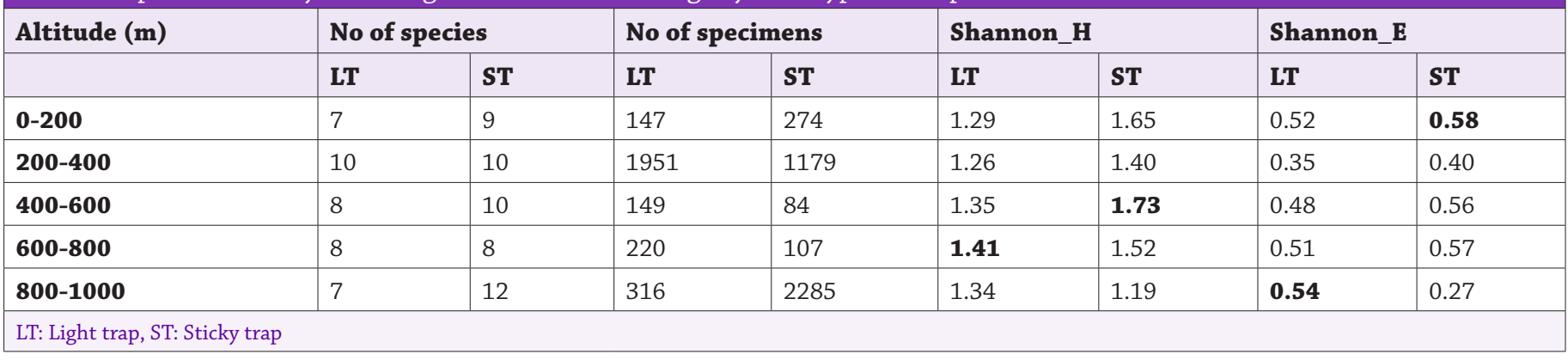


found, is in the only locality with both high number of species and specimens. On the other hand, the Shannon index showed the highest species diversity in Ortakayacık (655 m) and Çarıklar (454 m) villages. Regarding sand flies belonging to Sergentomyia genus, $S$. dentata was the dominant species, and according to the Shannon index, the species diversity was observed in $S$. minuta the most according to the villages.

\section{CONCLUSION}

In our study, nine and three sand fly species belonging to the Phlebotomus and Sergentomyia genera were identified, respectively. Phlebotomus tobbi, P. major s.l. and P. sergenti s.l., which are possible or proven vectors of $L$. infantum and $L$. tropica have been found in the Aydın Mountains and its environs and contribution to the previous fauna studies has been made. It was found that these three dominant species were active for seven months between April and October, P. sergenti s.l. was intense in the altitudinal range of $400-600 \mathrm{~m}$ in July while P. major s.l. and $P$. tobbi were intense in the altitudinal range of $200-400 \mathrm{~m}$ in September. These results are important in terms of revealing the time intervals in which the infection in the region is more, months for intense vector control efforts and appropriate vector control strategy to applied.

The results of this study and previous studies show that the activity of sand flies starts in April in Turkey, especially in leishmaniasis endemic areas where the Mediterranean climate is dominant and ends at the end of September after the populations of different species reach one or two peaks depending on the temperature. In the endemic areas located in high altitudes where the continental climate is dominant, it has been determined by studies that the populations can reach only one peak. However, it should be noted that the climate may change every year, and the possibility of seasonal activity of sand flies being slightly different should not be ignored. In addition, it should not be forgotten that the risk of transmission of the parasite may be high when populations show $\operatorname{peak}(\mathrm{s})$.

\section{*ACKNOWLEDGMENTS}

The present study is taken from Suha K. Arserim's Ph.D. thesis.

\section{* Ethics}

Ethics Committee Approval: Not applicable. Our work involved sand flies from the wild.

Informed Consent: No patients or animals were involved in the study.

Peer-review: Internally peer-reviewed.

\section{* Authorship Contributions}

Consept: S.K.A., Y.Ö., A.M., Design: S.K.A., Y.Ö., A.M., Data Collection or Processing: S.K.A., Analysis or Interpretation: S.K.A., Y.Ö., A.M., Literature Search: S.K.A., Y.Ö., Writing: S.K.A., Y.Ö.

Conflict of Interest: No conflict of interest was declared by the authors.

Financial Disclosure: This research did not receive any specific grant from funding agencies in the public, commercial, or not-forprofit sectors.

Supplementary: https://cms.galenos.com.tr/SolvePark/ Uploads/Files/turkish-journal-of-parasitology-2022-1-suppl.pdf

\section{REFERENCES}

1. Tesh RB. The genus Phlebovirus and its vectors. Annu Rev Entomol 1988; 33: 169-81.

2. Comer JA, Tesh RB. Phlebotomine sand flies as vectors of vesiculoviruses: a review. Parassitologia 1991; 33: 143-50.

3. Desjeux P. Leishmaniasis: Public health aspects and control. Clin Dermatol 1996; 14: 417-23.

4. Birtles RJ. Carrion's disease. In: MW. Service (ed) The encyclopedia of arthropod-transmitted infections, CABI Publishing: Wallingford; 2001.p.104-106.

5. Ashford RW. Phlebotomus fevers. In: MW. Service (ed), The encyclopedia of arthropod- transmitted infections. CABI Publishing: Wallingford; 2001.p. 397-401.

6. Ivović V, Patakakis M, Tselentis $Y$, Chaniotis B. Faunistic study of sandflies in Greece. Med Vet Entomol 2007; 21: 121-4.

7. Maroli M, Feliciangeli MD, Bichaud L, Charrel RN, Gradoni, L. Phlebotomine sandflies and the spreading of leishmaniases and other diseases of public health concern. Med Vet Entomol 2013; 27: 123-47.

8. Brazil RP, Rodrigues AAF, Filho JDA. Sand fly vectors of Leishmania in the Americas- a mini review. Entomol Ornithol Herpetol 2015; 4: 144.

9. Galati E, Galvis-Ovallos F, Lawyer P, Léger N, Depaquit, J. An illustrated guide for characters and terminology used in descriptions of Phlebotominae (Diptera, Psychodidae). Parasite 2017; 24: 26.

10. Daldal N, Özbel Y. Phlebotomus spp. vektörlükleri ve kontrolü, Parazitoloji'de Arthropod hastalıkları ve vektörler, Özcel MA ve Daldal N (ed.) Türkiye Parazitoloji Derg. Yay. no:13, Ege Üniv. Basımevi, İzmir; 1997.p.49-109.

11. World Health Organization. Control of the leishmaniasis: report of a meeting of the WHO Expert Committee on the Control of Leishmaniasis. Geneva. 2010.WHO Technical Report Series, 949.

12. Ghorbani M, Farhoudi R. Leishmaniasis in humans: drug or vaccine therapy. Drug Des Devel Ther 2017; 12: 25-40.

13. Handman E. Leishmaniasis: current status of vaccine development. Clin Microbiol Rev 2001; 14: 229-43.

14. Davies CR, Kaye P, Croft SL, Sundar S. Leishmaniasis: new approaches to disease control. BMJ 2003; 326: 377-82.

15. Özbilgin A, Töz S, Harman M, Günaştı Topal S, Uzun S, Okudan F, et al. The current clinical and geographical situation of cutaneous leishmaniasis based on species identification in Turkey. Acta Tsrop 2019; 190: 59-67.

16. Yaman M. Phlebotominae species (Diptera: Psychodidae) in Konya province (dissertation). Selçuk University, Institute of Health Sciences; 1999.

17. Ertabaklar H, Oncü S, Ertug S. A new focus for cutaneous leishmaniasis in the West Coast of Turkey. Trop Doct 2005; 35: 189.

18. Özbel Y, Balcıoğlu IC, Ölgen MK, Simsek FM, Töz SÖ, Ertabaklar, et al. Spatial distribution of phlebotomine sand flies in the Aydın Mountains and surroundings: the main focus of cutaneous leishmaniasis in western Turkey. J Vector Ecol 2011; 36(Suppl 1): S99-S105.

19. Theodor O. Psychodidae-Phlebotominae. In: Die Fliegen Der Palaerktischen Region Lindner E. (ed.), E. Schweizerbart'sche Verlagsbuchhandlung, Stuttgart; 1958.p.1-55.

20. Perfil'ev PP. Phlebotomidae (Sandflies). Fauna of USSR (Diptera). Academy of Sciences of the U.S.S.R. (Transl. by Israel Program for Scientific Translations) Wiener Bindery Ltd., Jerusalem; 1968; 3: 1-362.

21. Lewis DJ. A taxonomic review of the genus Phlebotomus (Diptera: Psychodidae). Bul br Mus nat Hist Entomol 1982; 45: 121-209.

22. Artemiev MM, Neronov V. Distribution and Ecology of Sandflies of the World (Genus Phlebotomus). Institute of Evolution. Morph Anim Ecol Moscow; 1984.p.207.

23. Killick-Kendrick R, Tang Y, Killick-Kendrick M, Sang DK, Sirdar MK, Ke L, et al. The identification of female sandflies of the subgenus Larroussius by the morphology of the spermathecal ducts. Parassitologia 1991; 33: $335-47$. 
24. Jørgensen SE, Costanza R, Xu FL. Handbook ecological indicators for assessment of ecosystem health. CRC Press/Taylor \& Francis, Boca Raton, USA; 2005.

25. Alptekin D, Kasap M, Luleyap U, Kasap H, Aksoy S, Wilson ML. Sandflies (Diptera: Psychodidae) associated with epidemic cutaneous leishmaniasis in Sanliurfa, Turkey. J Med Entomol 1999; 36: 277-81.

26. Volf P, Ozbel Y, Akkafa F, Svobodová M, Votýpka, J, Chang KP. Sand flies (Diptera: Phlebotominae) in Sanliurfa, Turkey: relationship of Phlebotomus sergenti with the epidemic of anthroponotic cutaneous leishmaniasis. J Med Entomol 2002; 39: 12-5.

27. Yaman M, Ozbel Y. The sandflies (Diptera: Psychodidae) in the Turkish province of Hatay: some possible vectors of the parasites causing human cutaneous leishmaniasis. Ann Trop Med Parasitol 2004; 98: 741-50.

28. Simsek FM, Alten B, Caglar SS, Ozbel Y, Aytekin AM, Kaynas S, et al. Distribution and altitudinal structuring of phlebotomine sand flies (Diptera: Psychodidae) in southern Anatolia, Turkey: their relation to human cutaneous leishmaniasis. J Vector Ecol 2007; 32: 269-79.

29. Killick-Kendrick R. Phlebotomine vectors of the leishmaniases: a review. Med Vet Entomol 1990; 4: 1-24.

30. Toprak S, Ozer N. Distribution of sand fly (Diptera: Psychodidae) species and efficiency of capturing methods in Sanliurfa province, Turkey. J Med Entomol 2007; 44: 23-8.

31. Svobodová M, Alten B, Zídková L, Dvorák V, Hlavacková J, Mysková J, et al. Cutaneous leishmaniasis caused by Leishmania infantum transmitted by Phlebotomus tobbi. Int J Parasitol 2009; 39: 251-6.

32. Erisoz-Kasap O, Belen A, Kaynas S, Simsek FM, Biler L, Ata N, et al. Activity Patterns of Sand Fly Species (Diptera: Psychodidae) and Comparative Performance of Different Traps in an Endemic Cutaneous leishmaniasis Focus in Cukurova Plain, Southern Anatolia. Acta Vet Brno 2009; 78: 327-35.

33. Belen A, Alten B. Seasonal dynamics and altitudinal distributions of sand fly (Diptera: Psychodidae) populations in a cutaneous leishmaniasis endemic area of the Cukurova region of Turkey. J Vector Ecol 2011; 36: 87-94.

34. Erisoz-Kasap O, Alten B. Comparative demography of the sand fly Phlebotomus papatasi (Diptera: Psychodidae) at constant temperatures. J Vector Ecol 2006; 31: 378-85.

35. Belen A, Alten B. Variation in life table characteristics among populations of Phlebotomus papatasi at different altitudes. J Vector Ecol 2006; 31: 35-44.

36. Erisoz-Kasap O, Linton YM, Karakus M, Ozbel Y, Alten B. Revision of the species composition and distribution of Turkish sand flies using DNA barcodes. Parasit Vectors 2019; 12: 410.

37. Chaniotis B, Spyridaki I, Scoulika E, Antoniou M. Colonization of Phlebotomus neglectus (Diptera: Psychodidae), the major vector of visceral leishmaniasis in Greece. J Med Entomol 2000; 37: 346-8.

38. Bosnić S, Gradoni L, Khoury C, Maroli M. A review of leishmaniasis in Dalmatia (Croatia) and results from recent surveys on phlebotomine sandflies in three southern counties. Acta Trop 2006; 99: 42-9.

39. Maroli M, Rossi L, Baldelli R, Capelli G, Ferroglio E, Genchi C, et al. The northward spread of leishmaniasis in Italy: evidence from retrospective and ongoing studies on the canine reservoir and phlebotomine vectors. Trop Med Int Health 2008; 13: 256-64.

40. Tok H, Sevil N, Ozensoy Töz S, Ertabaklar H, Balcıoğlu IC, Demir S, et al. The serological and entomological survey of zoonotic visceral leishmaniasis in Ayvacik Region of Canakkale Province, Turkey. Turkiye Parazitol Derg 2009; 33: 109-13.

41. Davies C. (Supervisor). Anthroponotic Cutaneous Leishmaniasis in Aydın, Turkey(dissertation). Master Thesis. University of London, Department of Infectious and Tropical Diseases. Candidate number: 6199, 2006. This reference can be obtained from the corresponding author upon request.

42. Papadopoulos B, Tselentis Y. Sandflies in the Greater Athens region, Greece. Parasite 1994; 1: 131-40.

43. Chaniotis B, Gozalo Garcia G, Tselentis Y. Leishmaniasis in greater Athens, Greece. Entomological studies. Ann Trop Med Parasitol 1994; 88: 659-63.

44. Lewis DJ, Phlebotomid sandflies. Bull World Health Organ 1971; 44: 535-51.

45. Depaquit J, Ferté H, Léger N, Lefranc F, Alves-Pires C, Hanafi H, et al. ITS 2 sequences heterogeneity in Phlebotomus sergenti and Phlebotomus similis (Diptera, Psychodidae): possible consequences in their ability to transmit Leishmania tropica. Int J Parasitol 2002; 32: 1123-31.

46. Ntais P, Sifaki-Pistola D, Christodoulou V, Messaritakis I, Pratlong F, Poupalos G, et al. Leishmaniases in Greece. Am J Trop Med Hyg 2013; 89: 906-15.

47. Velo E, Paparisto A, Bongiorno G, Di Muccio T, Khoury C, Bino S, et al. Entomological and parasitological study on phlebotomine sandflies in central and northern Albania. Parasite 2005; 12: 45-9.

48. Guan LR, Xu YX, Li BS, Dong J. The role of Phlebotomus alexandri Sinton, 1928 in the transmission of kala-azar. Bull World Health Organ 1986; 64: 107-12.

49. Azizi K, Rassi Y, Javadian E, Motazedian MH, Rafizadeh S, Yaghoobi Ershadi MR, et al. Phlebotomus (Paraphlebotomus) alexandri: a probable vector of Leishmania infantum in Iran. Ann Trop Med Parasitol 2006; 100: 63-8.

50. Limoncu ME, Balcığlu İC, Töz S, Demir S, Kavur H, Karakuş, et al. Entomological Survey for the Detection of Sand Fly Fauna and Vector Species in the Cutaneous Leishmaniasis Endemic Area in East Mediterranean Region of Turkey, Mersin Province. J Med Entomol 2020; 57: 1510-15.

51. Özbilgin A, Harman M, Karakuş M, Bart A, Töz S, Kurt Ö, et al. Leishmaniasis in Turkey: Visceral and cutaneous leishmaniasis caused by Leishmania donovani in Turkey. Acta Trop 2017; 173: 90-6.

52. Sarı B, Limoncu ME, Balcioglu IC, Aldemir A, Tasci GT, Kiliç Y, et al. Seroepidemiological and entomological survey in a new focus of zoonotic visceral leishmaniasis in Kars province, Northeastern Turkey. Vet Parasitol 2015; 209: 179-87.

53. Karmaoui A. Seasonal Distribution of Phlebotomus papatasi, Vector of Zoonotic Cutaneous Leishmaniasis. Acta Parasitol 2020; 65: 585-98.

54. Doha SA, Samy AM. Bionomics of phlebotomine sand flies (Diptera: Psychodidae) in the province of Al-Baha, Saudi Arabia. Mem Inst Oswaldo Cruz 2010; 105: 850-6. 